\title{
Zerumbone and Kaempferol Derivatives from the Rhizomes of Zingiber montanum (J. Koenig) Link ex A. Dietr. from Bangladesh
}

\author{
Md. Mahadi Hassan ${ }^{1,2}$, Anjana Adhikari-Devkota ${ }^{1}$, Teruko Imai ${ }^{1}$ \\ and Hari Prasad Devkota $1,2, *$ (D) \\ 1 Graduate School of Pharmaceutical Sciences, Kumamoto University, 5-1 Oe-honmachi, Chuo-ku, Kumamoto \\ 862-0973, Japan; mahadihassan1@gmail.com (M.M.H.); adhikarianjana@gmail.com (A.A.-D.); \\ iteruko@gpo.kumamoto-u.ac.jp (T.I.) \\ 2 Program for Leading Graduate Schools, Health Life Science: Interdisciplinary and Glocal Oriented (HIGO) \\ Program, Kumamoto University, 5-1 Oe-honmachi, Chuo-ku, Kumamoto 862-0973, Japan \\ * Correspondence: devkotah@kumamoto-u.ac.jp; Tel.: +81-96-371-4837
}

Received: 10 May 2019; Accepted: 5 June 2019; Published: 17 June 2019

\begin{abstract}
Zingiber montanum (J. Koenig) Link ex A. Dietr. (Zingiberaceae) is known as "Banada" in Bangladesh, and the rhizomes are frequently used in traditional medicines for the treatment of constipation, dyspepsia, flatulence, stomach bloating, and as mosquito repellant. In this study, dried rhizomes were extracted successively with $95 \%$ and $50 \%$ ethanol and the combined extract was then subjected to various column chromatographic methods to isolate one sesquiterpenoid derivative, zerumbone (1) and five kaempferol derivatives, i.e., kaempferol 3-O-methyl ether (2), kaempferol 3-O- $\alpha$-rhamnopyranoside (3), kaempferol 3-O- $\alpha$-(4"-O-acetyl)rhamnopyranoside (4), kaempferol 3-O- $\alpha$-(3"-O-acetyl)rhamnopyranoside (5), and kaempferol 3-O- $\alpha$-(3",4"-di-O-acetyl)rhamnopyranoside (6). All compounds except 1 were isolated for the first time from the title plant.
\end{abstract}

Keywords: Zingiber montanum; Zingiberaceae; zerumbone; flavonoids; kaempferol

\section{Introduction}

The Zingiberaceae family has about 50 genera distributed all over the world but mostly in Asia, Central America and Africa. Many plants of Zingiberaceae family are used as food, spice, and medicines [1]. The genus Zingiber consists of about 85 species [2] that are used for various purposes as food and medicine. Among them, Zingiber officinale Roscoe is the most widely used one. In Bangladesh, eight species of the genus Zingiber have been found, namely Z. capitatum Roxb., Z. montanum (J. Koenig) Link ex A. Dietr., Z. officinale Roscoe, Z. zerumbet (L.) Roscoe ex Sm., Z. roseum Roxb., Z. rubens Roxb., Z. salarkhanii Rahman et Yusuf. [3], and Z. spectabile Griff. [4].

Zingiber montanum (J. Koenig) Link ex A. Dietr. (Syns: Amomum cassumunar (Roxb.) Donn, Amomum montanum J. Koenig, Amomum xanthorhiza Roxb. ex Steud., Cassumunar roxburghii Colla, Jaegera montana (J. Koenig) Giseke, Zingiber anthorrhiza Horan., Zingiber cassumunar Roxb., Zingiber cassumunar var. palamauense Haines, Zingiber cassumunar var. subglabrum Thwaites, Zingiber cliffordiae Andrews, Zingiber luridum Salisb., Zingiber montanum (J. König ex Retz.) Theilade, Zingiber purpureum Roscoe, Zingiber purpureum var. palamauense (Haines) K.K.Khanna, Zingiber xantorrhizon Steud.) [5] is considered to be native to India and Bangladesh. It is also widely distributed in tropical countries [6] in Southeast Asia and cultivated in Thailand, Malaysia, and Indonesia [7]. In Bangladesh, it is commonly known as "Banada", meaning wild ginger. The rhizomes of Z. montanum are used traditionally to treat constipation, dyspepsia, flatulence, stomach bloating, and as mosquito repellant [8-10]. Previous 
pharmacological studies of Z. montanum have reported antimicrobial [11], anti-inflammatory [12,13], antioxidant [11], antihistaminic, smooth muscle relaxant [14], antifungal [15], insecticidal activity [16] and anticholinesterase activities [17]. There have been many studies on the volatile constituents of the rhizomes of $Z$. montanum and (E)-1-(3,4-dimethoxyphenyl)butadiene, terpinen-4-ol and $\gamma$-terpinene [18], 1,4-bis (methoxy) triquinacene, (Z)-ocimene, terpinen-4-ol, $\gamma$;-terpinene, and $\beta$-phellandrene [19] were reported as its main constituents. A sesquiterpenoid, zerumbone as an antiulcer compound [8] and the complex curcuminoids, cassumunins A, B, C [12] and cassumunarins A, B, C [20] with potent antioxidant activities were also isolated from the rhizomes.

Various Zingiber plants including Z. montanum are reported to be used as a substitute and/or adulterant of $Z$. officinalis [21,22]. Recently, $Z$. montanum was also reported as an invasive species in many countries [22]. For the proper utilization of this plant, the detailed chemical analysis of bioactive compounds is necessary. Although there are many studies on volatile constituents of Z. montanum, very few studies have reported non-volatile constituents including phenolic compounds. Thus, in this study, we aimed for the isolation and identification of compounds from Z. montanum collected from Bangladesh.

\section{Materials and Methods}

\subsection{General Experimental Procedures}

${ }^{1} \mathrm{H}-,{ }^{13} \mathrm{C}$ - and 2D-NMR spectra were measured on an AVANCE 600 NMR spectrometer (Bruker, Billerica, MA, USA) $\left({ }^{1} \mathrm{H}-\mathrm{NMR}: 600 \mathrm{MHz}\right.$ and $\left.{ }^{13} \mathrm{C}-\mathrm{NMR}: 150 \mathrm{MHz}\right)$. Chemical shift values $\left(\delta_{\mathrm{H}}\right.$ and $\left.\delta_{\mathrm{C}}\right)$ are given in ppm with reference to tetramethylsilane (TMS). Column chromatography was carried out with MCI gel CHP20P (75-150 $\mu \mathrm{m}$, Mitsubishi Chemical Industries Co. Ltd., Tokyo, Japan), Sephadex LH-20 (Amersham Pharmacia Biotech, Tokyo, Japan), and silica gel 60 (0.040-0.063 mm, Merck KGaA, Darmstadt, Germany). Thin layer chromatography (TLC) was performed on a precoated silica gel $60 \mathrm{~F}_{254}$ (Aluminum sheet, Merck KGaA, Darmstadt, Germany). Structures of compounds were drawn using the software ChemBioDraw Ultra 14.0 (CambridgeSoft Corporation, PerkinElmer Inc., Cambridge, MA, USA).

\subsection{Plant Materials}

Fresh rhizomes of Z. montanum were collected from Gazipur central area, Gazipur district, Bangladesh in January 2018 and identified by Dr. Mohammad Sayedur Rahman, Senior Scientist, Bangladesh National Herbarium, Dhaka, Bangladesh. A voucher specimen (No. DACB-45749) is deposited at the Museum of Bangladesh National Herbarium.

\subsection{Extraction and Isolation}

Shade dried rhizomes of Z. montanum (1200 g) were extracted successively with $95 \% \mathrm{EtOH}$ and $50 \%$ ( $8 \mathrm{~L}$, two times each for $72 \mathrm{~h}$ ) at room temperature. The filtered extracts were then combined and evaporated by using a rotary evaporator to obtain $132.5 \mathrm{~g}$ of dried extract. The extract was then suspended in water $(1000 \mathrm{~mL})$ and extracted with hexane $(1000 \mathrm{~mL}, 3$ times) to obtain a hexane fraction and a water-soluble fraction. The hexane fraction $(28.6 \mathrm{~g})$ was subjected to silica gel CC (Hex: EtOAc $=10: 1)$ to obtain compound $\mathbf{1}(6412.0 \mathrm{mg})$. The water-soluble fraction $(101.0 \mathrm{~g})$ was subjected to MCI gel CHP20P column chromatography (CC) and eluted successively with water, $40 \%, 70 \%$ and $100 \% \mathrm{MeOH}$ to give 11 fractions (1-11). Among them, fraction $5(1.6 \mathrm{~g}), 6(1.0 \mathrm{~g})$ and $7(1.3 \mathrm{~g})$ were mixed and subjected to silica gel $\mathrm{CC}\left(\mathrm{CH}_{2} \mathrm{Cl}_{2}: \mathrm{MeOH}: \mathrm{H}_{2} \mathrm{O}=9: 1: 0.1\right)$ to afford 6 fractions (Fr. 5-1-5-6). Subfraction 5-2 (1.3 g) was further subjected to silica gel CC $\left(\mathrm{CH}_{2} \mathrm{Cl}_{2}: \mathrm{MeOH}: \mathrm{H}_{2} \mathrm{O}=9: 1: 0.1\right)$ to obtain compound $6(34.0 \mathrm{mg})$. Subfraction 5-3 $(340 \mathrm{mg})$ was subjected to silica gel CC $\left(\mathrm{CH}_{2} \mathrm{Cl}_{2}: \mathrm{MeOH}\right.$ : $\left.\mathrm{H}_{2} \mathrm{O}=9: 1: 0.1\right)$ to obtain compound $5(5.1 \mathrm{mg})$. Fraction 5-4 $(170 \mathrm{mg})$ was subjected to silica gel CC $\left(\mathrm{CH}_{2} \mathrm{Cl}_{2}: \mathrm{MeOH}: \mathrm{H}_{2} \mathrm{O}=\right.$ 9:1:0.1) to obtain seven subfractions (5-4-1 5-4-7). Subfraction 5-4-2 (65 mg) was again subjected to silica gel $\mathrm{CC}\left(\mathrm{CH}_{2} \mathrm{Cl}_{2}: \mathrm{MeOH}: \mathrm{H}_{2} \mathrm{O}=9: 1: 0.1\right)$ to obtain compound $4(15.3 \mathrm{mg})$. 
Subfraction 5-4-5 was obtained as compound $3(33.6 \mathrm{mg})$. Subfr. 5-5 (100 mg) was subjected to silica gel CC $\left(\mathrm{CH}_{2} \mathrm{Cl}_{2}: \mathrm{MeOH}: \mathrm{H}_{2} \mathrm{O}=\right.$ 9:1:0.1) to obtain compound 2 (13.9 mg) (Figure 1).

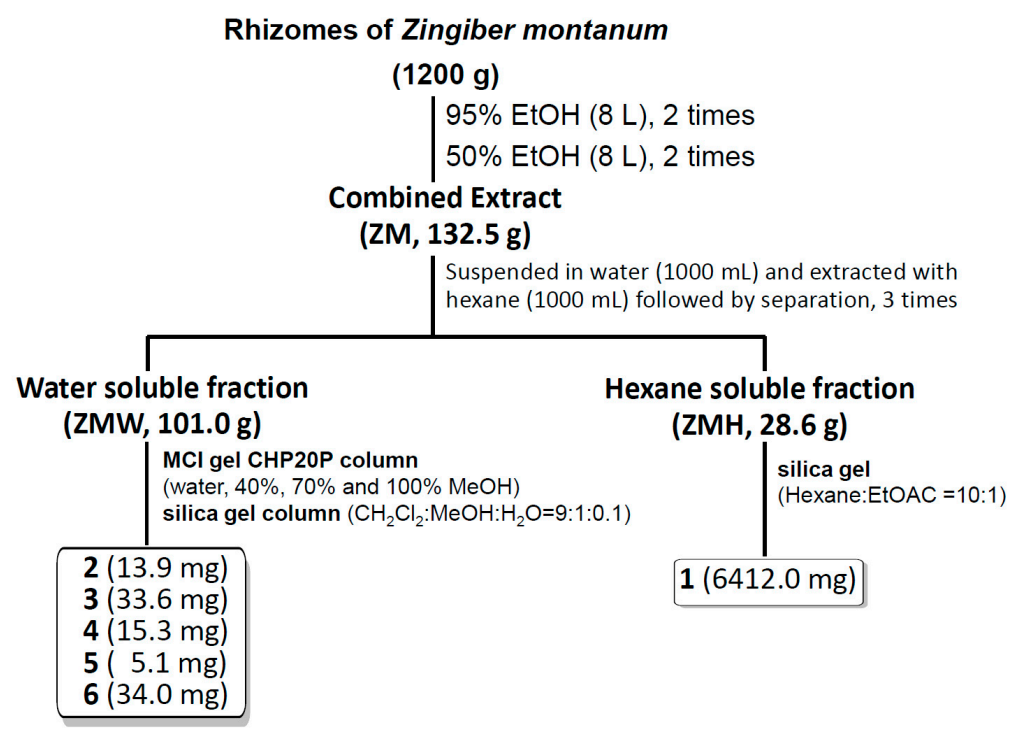

Figure 1. Schematic flowchart of extraction and isolation of compounds from the rhizomes of Zingiber montanum.

\section{Results and Discussion}

The detailed chemical analysis of rhizomes of Z. montanum afforded a sesquiterpenoid derivative, zerumbone (1) [23] and five flavonoid derivatives, kaempferol 3-O-methyl ether (2) [23], kaempferol 3-O- $\alpha$-rhamnopyranoside (3) [24,25], kaempferol 3-O- $\alpha$-(4"-O-acetyl) rhamnopyranoside (4) $[25,26]$, kaempferol 3-O- $\alpha-(3 "-O$-acetyl) rhamnopyranoside (5) [25] and kaempferol 3-O- $\alpha-(3 "$, 4"-di-O-acetyl)rhamnopyranoside (6) [23] (Figure 2). Compound 6 was obtained as a mixture with compounds 4 and 5. Structures of these compounds were elucidated on the basis of NMR spectral data (Table 1 for compound 1 and Table 2 for compounds 2-6) and comparison to literature values. To the best of our knowledge, all compounds except 1 were isolated for the first time from $Z$. montanum.<smiles>CC(C)=CCCC(C)=CC(=O)C(C)(C)C</smiles>

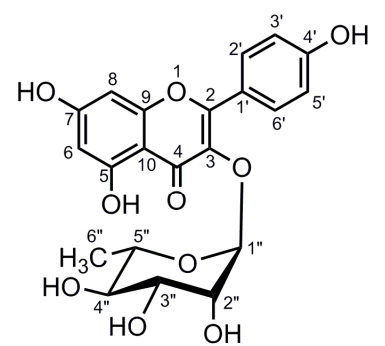<smiles>COc1c(-c2ccc(O)cc2)oc2cc(O)cc(O)c2c1=O</smiles>

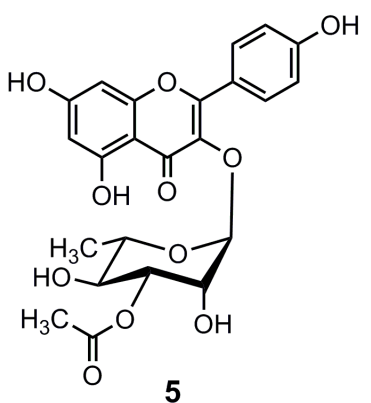

5<smiles></smiles>

Figure 2. Structures of compounds isolated from the rhizomes of Zingiber montanum. 
Table 1. NMR spectroscopic data of compound 1 in $\mathrm{CDCl}_{3}$.

\begin{tabular}{|c|c|c|c|c|c|}
\hline Position & $\delta_{\mathrm{C}}$ & $\delta_{\mathrm{H}}$, mult. $(J$ in $\mathrm{Hz})$ & Position & $\delta_{\mathrm{C}}$ & $\delta_{\mathrm{H}}$, mult. $(J$ in $\mathrm{Hz})$ \\
\hline 1 & 42.4 & $\begin{array}{c}1.89, \text { brd }(16.0) \\
2.22-2.46, \mathrm{~m}\end{array}$ & 9 & 127.2 & $5.96, \mathrm{~d}(16.4)$ \\
\hline 2 & 125.0 & 5.25, brd (15.3) & 10 & 160.7 & $5.86, \mathrm{~d}(16.4)$ \\
\hline 3 & 136.3 & & 11 & 37.9 & \\
\hline 4 & 39.4 & $2.22-2.46, \mathrm{~m}$ & 12 & 15.2 & $1.54, \mathrm{~s}$ \\
\hline 5 & 29.4 & $2.22-2.46, \mathrm{~m}$ & 13 & 11.8 & $1.80, \mathrm{~s}$ \\
\hline 6 & 148.8 & 6.01, brd (11.3) & 14 & $24.2^{\mathrm{a}}$ & $1.20, \mathrm{~s}^{\mathrm{a}}$ \\
\hline 7 & 138.0 & & 15 & $24.4^{\mathrm{a}}$ & $1.08, \mathrm{~s}^{\mathrm{a}}$ \\
\hline 8 & 204.3 & & & & \\
\hline
\end{tabular}

a Assignments may be interchanged within the same column. Abbreviations: $\delta_{\mathrm{C}}$ : chemical shift in ppm for ${ }^{13} \mathrm{C}-\mathrm{NMR}$, $\delta_{\mathrm{H}}$ : chemical shift in ppm for ${ }^{1} \mathrm{H}-\mathrm{NMR}$; mult.: multiplicity; $J$ in Hz: coupling constants in Hz; brd: broad doublet; $\mathrm{d}$ : doublet, m: multiplet, s: singlet.

Table 2. NMR spectroscopic data of compounds $\mathbf{2}-\mathbf{6}$ in $\mathrm{CD}_{3} \mathrm{OD}$.

\begin{tabular}{|c|c|c|c|c|c|c|c|c|c|c|}
\hline \multirow[b]{2}{*}{ Position } & \multicolumn{2}{|c|}{ Compound 2} & \multicolumn{2}{|c|}{ Compound 3} & \multicolumn{2}{|c|}{ Compound 4} & \multicolumn{2}{|c|}{ Compound 5} & \multicolumn{2}{|c|}{ Compound 6} \\
\hline & $\delta_{\mathrm{C}}$ & $\begin{array}{l}\delta_{\mathrm{H}}, \text { mult. } \\
(J \text { in } \mathrm{Hz})\end{array}$ & $\delta_{C}$ & $\begin{array}{l}\delta_{\mathrm{H}}, \text { mult. } \\
(J \text { in } \mathrm{Hz})\end{array}$ & $\delta_{C}$ & $\begin{array}{l}\delta_{\mathrm{H}}, \text { mult. } \\
(J \text { in } \mathrm{Hz})\end{array}$ & $\delta_{C}$ & $\begin{array}{l}\delta_{\mathrm{H}}, \text { mult. } \\
(J \text { in } \mathrm{Hz})\end{array}$ & $\delta_{\mathrm{C}}$ & $\begin{array}{l}\delta_{\mathrm{H}}, \text { mult. } \\
(J \text { in } \mathrm{Hz})\end{array}$ \\
\hline 2 & 157.6 & & 159.2 & & 158.6 & & 159.2 & & 159.2 & \\
\hline 3 & 139.5 & & 136.2 & & 135.6 & & 136.0 & & 135.6 & \\
\hline 4 & 180.1 & & 179.6 & & 179.5 & & 179.6 & & 179.4 & \\
\hline 5 & 163.1 & & 163.2 & & 163.2 & & 163.2 & & 163.2 & \\
\hline 6 & 99.8 & $\begin{array}{c}6.20, \mathrm{~d} \\
(2.0)\end{array}$ & 99.0 & $\begin{array}{c}6.19, \mathrm{~d} \\
(2.0)\end{array}$ & 99.6 & $\begin{array}{l}6.21, \mathrm{~d} \\
(2.1)\end{array}$ & 99.9 & $\begin{array}{c}6.19, \mathrm{~d} \\
(2.0)\end{array}$ & 100.4 & $\begin{array}{c}6.20, \mathrm{~d} \\
(2.0)\end{array}$ \\
\hline 7 & 165.9 & & 165.8 & & 165.9 & & 165.9 & & 165.9 & \\
\hline 8 & 94.6 & $\begin{array}{c}6.40, \mathrm{~d} \\
(2.0)\end{array}$ & 94.8 & $\begin{array}{c}6.36, \mathrm{~d} \\
(2.0)\end{array}$ & 94.8 & $\begin{array}{c}6.38, \mathrm{~d} \\
(2.1)\end{array}$ & 94.8 & $\begin{array}{c}6.38, \mathrm{~d} \\
(2.0)\end{array}$ & 94.8 & $\begin{array}{c}6.52, \mathrm{~d} \\
(2.0)\end{array}$ \\
\hline 9 & 158.1 & & 158.5 & & 159.4 & & 158.6 & & 158.6 & \\
\hline 10 & 105.7 & & 106.0 & & 105.9 & & 106.0 & & 105.9 & \\
\hline $1^{\prime}$ & 122.2 & & 122.7 & & 122.6 & & 122.6 & & 122.5 & \\
\hline $2^{\prime}, 6^{\prime}$ & 131.4 & $\begin{array}{c}7.99, \mathrm{~d} \\
(8.7)\end{array}$ & 131.9 & $\begin{array}{c}7.76, \mathrm{~d} \\
(8.7)\end{array}$ & 131.9 & $\begin{array}{c}7.81, \mathrm{~d} \\
(8.9)\end{array}$ & 131.9 & $\begin{array}{c}7.80, \mathrm{~d} \\
(8.9)\end{array}$ & 131.8 & $\begin{array}{c}7.81, \mathrm{~d} \\
(8.8)\end{array}$ \\
\hline $3^{\prime}, 5^{\prime}$ & 116.4 & $\begin{array}{c}6.93, \mathrm{~d} \\
(8.7)\end{array}$ & 116.5 & $\begin{array}{c}6.94, \mathrm{~d} \\
(8.7)\end{array}$ & 116.5 & $\begin{array}{c}6.96, \mathrm{~d} \\
(8.8)\end{array}$ & 116.6 & $\begin{array}{c}6.93, \mathrm{~d} \\
(8.9)\end{array}$ & 116.6 & $\begin{array}{c}6.96, \mathrm{~d} \\
(8.8)\end{array}$ \\
\hline $4^{\prime}$ & 161.7 & & 161.5 & & 161.7 & & 161.6 & & 161.7 & \\
\hline $3-\mathrm{OCH}_{3}$ & 60.4 & $3.78, \mathrm{~s}$ & & & & & & & & \\
\hline $1^{\prime \prime}$ & & & 103.5 & $\begin{array}{c}5.38, \mathrm{~d} \\
(1.5)\end{array}$ & 102.5 & $\begin{array}{c}5.51, \mathrm{~d} \\
(1.5)\end{array}$ & 103.0 & $\begin{array}{c}5.50, \mathrm{~d} \\
(1.3)\end{array}$ & 102.5 & $\begin{array}{c}5.59, \mathrm{~d} \\
(1.3)\end{array}$ \\
\hline $2^{\prime \prime}$ & & & 72.0 & 4.22 , brs & 71.7 & 4.21 , brs & 69.7 & 4.36 , brs & 72.1 & 4.34 , brs \\
\hline $3^{\prime \prime}$ & & & 72.1 & $3.73, \mathrm{~m}$ & 70.1 & $\begin{array}{l}3.84, \mathrm{dd} \\
(3.4,9.8)\end{array}$ & 75.3 & $\begin{array}{l}4.97, \mathrm{dd} \\
(3.2,9.8)\end{array}$ & 69.4 & $\begin{array}{l}5.16, \mathrm{dd} \\
(3.2,9.8)\end{array}$ \\
\hline $4^{\prime \prime}$ & & & 73.2 & $\begin{array}{c}3.31-3.34 \\
\mathrm{~m}\end{array}$ & 74.9 & $\begin{array}{l}4.82, \mathrm{dd} \\
(9.8,9.9)\end{array}$ & 70.4 & $3.63, \mathrm{~m}$ & 71.9 & $5.07, \mathrm{t}(9.8)$ \\
\hline $5^{\prime \prime}$ & & & 71.9 & $\begin{array}{c}\text { 3.31-3.34 } \\
\mathrm{m}\end{array}$ & 69.6 & $3.22, \mathrm{~m}$ & 71.7 & $3.40, \mathrm{~m}$ & 69.4 & $3.44, \mathrm{~m}$ \\
\hline $6^{\prime \prime}$ & & & 17.6 & $\begin{array}{c}0.98, \mathrm{~d} \\
(5.6)\end{array}$ & 17.5 & $\begin{array}{l}0.77, \mathrm{~d} \\
(6.2)\end{array}$ & 17.7 & $\begin{array}{c}0.94, \mathrm{~d} \\
(6.2)\end{array}$ & 17.5 & $\begin{array}{c}0.80, \mathrm{~d} \\
(6.2)\end{array}$ \\
\hline $\mathrm{COCH}_{3}$ & & & & & 172.4 & & 172.7 & & $\begin{array}{l}171.5 \\
172.1\end{array}$ & \\
\hline $\mathrm{COCH}_{3}$ & & & & & 20.9 & $2.03, \mathrm{~s}$ & 21.1 & $2.12, \mathrm{~s}$ & $\begin{array}{l}20.7 \\
20.9\end{array}$ & $\begin{array}{l}1.97, \mathrm{~s} \\
2.06, \mathrm{~s}\end{array}$ \\
\hline
\end{tabular}

Abbreviations: $\delta_{\mathrm{C}}$ : chemical shift in ppm for ${ }^{13} \mathrm{C}-\mathrm{NMR} ; \delta_{\mathrm{H}}$ : chemical shift in ppm for ${ }^{1} \mathrm{H}-\mathrm{NMR}$; mult.: multiplicity; in Hz: coupling constants in Hz; brs: broad singlet; d: doublet, dd: double doublet, m: multiple, s: singlet; t: triplet.

Zerumbone (1) was isolated in 1960 from Z. zerumbet Smith [27] and structurally characterized in 1965 [28]. Other than Z. zerumbet [25,29-31], it has also been reported from Z. montanum [8], Z. spectabile [4] and Z. aromaticum [31]. However, it should be noted that Dai et al. [31] reported Z. zerumbet and $Z$. aromaticum as separate species collected from the Philippines and Indonesia, respectively but The Plant List [5] currently includes Z. aromaticum Valeton as a synonym of Z. zerumbet (L.) Roscoe ex Sm. Thus, in the following discussion, the plant source names that authors mentioned in their articles are used irrespective of their current taxonomic classification. There have been extensive studies on zerumbone regarding various biological activities [32], including anti-inflammatory activity 
in acute lung injury after lipopolysaccharide (LPS) administration in mice [33], antiparasitic activity in protozoa [34], antioxidant, gastroprotective, antisecretory and anti- Helicobacter pylori activities [35], and protection of pancreatic $\beta$ cell in high glucose induced apoptosis [36]. Similarly, it is reported to be effective in anticancer activity in human breast cancer [37], mouse skin cancer [38] and human cervical cancer cell lines [39]. It is also reported to be effective in protecting ultraviolet B-treated mice from cataractogenesis and photokeratitis [40]. As zerumbone was isolated in a large quantity from $Z$. montanum in our study, it may serve as a suitable source for the isolation of this bioactive compound.

Five kaempferol derivatives (2-6) isolated in this study have been reported to be present in many other plant species of the Zingibereceae family, and it showed a particularly close resemblance with Z. zerumbet. Kaempferol 3-O-methyl ether (2) was isolated previously from the rhizomes of Z. zerumbet [25,41,42], Z. spectabile [4], Z. aromaticum [43], and Roscoea purpurea [44], among others. Similarly, kaempferol 3-O- $\alpha$-rhamnopyranoside (3) was isolated and identified from Z. ottensii [45], $Z$. aromaticum [42,43], and Z. zerumbet [30]. Kaempferol 3-O- $\alpha$-(4"-O-acetyl) rhamnopyranoside (5) was isolated from Z. zerumbet [30,31,42], Z. spectabile [4,46], and Z. aromaticum [43]. Kaempferol 3-O- $\alpha$-(3"-O-acetyl)rhamnopyranoside (5) was isolated from Z. zerumbet [25,30,42], Z. spectabile [4], Z. ottensii [45], and Z. aromaticum [43]. Kaempferol 3-O- $\alpha$-(3",4"-di-O-acetyl) rhamnopyranoside (6) was isolated from Z. zerumbet [23,29,30], Z. spectabile [4,46], Z. ottensii [45], and Z. aromaticum [31,43].

Recently, Jiang et al. [21] reported that Z. zerumbet and Z. montanum were closely related to $Z$. officinale on the basis of molecular analysis and volatile chemical constituents analysis, respectively. In this study, we observed that the major constituents (zerumbone and flavonoids) isolated form $Z$. montanum were isolated previously from $Z$. zerumbet, which showed its close resemblance with later species. Z. montanum may have the potential to be used as an alternative to Z. zerumbet as a spice and in medicines. However, further studies are necessary to provide more detailed chemotaxonomic evidences in the future.

\section{Conclusions}

In conclusion, one sesquiterpenoid derivative, zerumbone (1) and five kaempferol derivatives (2-6) were isolated from the rhizomes of Z. montanum collected in Bangladesh. Further studies should be focused on the biological activity analysis of these compounds.

Author Contributions: T.I. and H.P.D. conceived and designed the experiments; M.M.H., A.A.-D., and H.P.D. performed the experiments and analyzed the data; M.M.H. and H.P.D. wrote the paper. All authors checked and approved the final version of manuscript.

Funding: This work was supported in part by the Program for Leading Graduate Schools "HIGO" (Health Life Science: Interdisciplinary and Glocal Oriented), MEXT, Japan and Program for Building Regional Innovation Ecosystems at Kumamoto University, Kumamoto, Japan.

Acknowledgments: We would like to thank Mohammad Sayedur Rahman, Senior Scientist, Bangladesh National Herbarium, Dhaka, Bangladesh for identifying the plant species.

Conflicts of Interest: Authors declare no conflicts of interest.

\section{References}

1. Sharifi-Rad, M.; Varoni, E.M.; Salehi, B.; Sharifi-Rad, J.; Matthews, K.R.; Ayatollahi, S.A.; Kobarfard, F.; Ibrahim, S.A.; Mnayer, D.; Zakaria, Z.A.; et al. Plants of the genus zingiber as a source of bioactive phytochemicals: From tradition to pharmacy. Molecules 2017, 22, 2145. [CrossRef] [PubMed]

2. Sabulal, B.; Dan, M.; John, A.J.; Kurup, R.; Pradeep, N.S.; Valsamma, R.K.; George, V. Caryophyllene-rich rhizome oil of Zingiber nimmonii from South India: Chemical characterization and antimicrobial activity. Phytochemistry 2006, 67, 2469-2473. [CrossRef] [PubMed]

3. Rahman, M.A.; Yusuf, M. Zingiber salarkhanii (Zingiberaceae), a new species from Bangladesh. Bangladesh J. Plant Taxon. 2013, 20, 239-242. [CrossRef] 
4. Sadhu, S.K.; Khatun, A.; Ohtsuki, T.; Ishibashi, M. First isolation of sesquiterpenes and flavonoids from Zingiber spectabile and identification of zerumbone as the major cell growth inhibitory component. Nat. Prod. Res. 2007, 21, 1242-1247. [CrossRef] [PubMed]

5. The Plant List. Available online: http://www.theplantlist.org/ (accessed on 19 April 2019).

6. Sanatombi, R.; Sanatombi, K. Biotechnology of Zingiber montanum (Koenig) Link ex A. Dietr.: A review. J. Appl. Res. Med. Aromat. Plants 2017, 4,1-4. [CrossRef]

7. Sirirugsa, P. Thai Zingiberaceae: Species Diversity and Their Uses. Pure Appl. Chem. 1998, 70, $23-27$.

8. Al-Amin, M.; Sultana, G.N.N.; Hossain, C.F. Antiulcer principle from Zingiber montanum. J. Ethnopharmacol. 2012, 141, 57-60. [CrossRef]

9. Manochai, B.; Paisooksantivatana, Y.; Choi, H.; Hong, J.H. Variation in DPPH scavenging activity and major volatile oil components of cassumunar ginger, Zingiber montanum (Koenig), in response to water deficit and light intensity. Sci. Hortic. (Amsterdam) 2010, 126, 462-466. [CrossRef]

10. Ozaki, Y.; Kawahara, N.; Harada, M. Anti-inflammatory Effect of Zingiber cassumunar ROXB. and Its Active Principles. Chem. Pharm. Bull. (Tokyo) 2011, 39, 2353-2356. [CrossRef]

11. Pithayanukul, P.; Tubprasert, J.; Wuthi-Udomlert, M. In vitro antimicrobial activity of Zingiber cassumunar (Plai) oil and a 5\% Plai oil gel. Phyther. Res. Int. J. Devot. Pharmacol. Toxicol. Eval. Nat. Prod. Deriv. 2007, 21, 164-169.

12. Masuda, T.; Jitoe, A. Antioxidative and Antiinflammatory Compounds from Tropical Gingers: Isolation, Structure Determination, and Activities of Cassumunins A, B, and C, New Complex Curcuminoids from Zingiber cassumunar. J. Agric. Food Chem. 1994, 42, 1850-1856. [CrossRef]

13. Panthong, A.; Kanjanapothi, D.; Niwatananun, V.; Tuntiwachwuttikul, P.; Reutrakul, V. Anti-inflammatory activity of compounds isolated from Zingiber cassumunar. Planta Med. 1990, 56, 655. [CrossRef]

14. Kanjanapothi, D.; Soparat, P.; Panthong, A.; Tuntiwachwuttikul, P.; Reutrakul, V. A Uterine Relaxant Compound from Zingiber cassumunar. Planta Med. 2007, 53, 329-332. [CrossRef] [PubMed]

15. bin Jantan, I.; Yassin, M.S.M.; Chin, C.B.; Chen, L.L.; Sim, N.L. Antifungal Activity of the Essential Oils of Nine Zingiberaceae Species. Pharm. Biol. 2003, 41, 392-397. [CrossRef]

16. Nugroho, B.W.; Schwarz, B.; Wray, V.; Proksch, P. Insecticidal constituents from rhizomes of Zingiber cassumunar and Kaempferia rotunda. Phytochemistry 1996, 41, 129-132. [CrossRef]

17. Okonogi, S.; Chaiyana, W. Enhancement of anti-cholinesterase activity of Zingiber cassumunar essential oil using a microemulsion technique. Drug Discov. Ther. 2012, 6, 249-255. [CrossRef]

18. Pongprayoon, U.; Soontornsaratune, P.; Jarikasem, S.; Sematong, T.; Wasuwat, S.; Claeson, P. Topical antiinflammatory activity of the major lipophilic constituents of the rhizome of Zingiber cassumunar. Part I: The essential oil. Phytomedicine 1997, 3, 319-322. [CrossRef]

19. Bhuiyan, M.N.I.; Chowdhury, J.U.; Begum, J. Volatile constituents of essential oils isolated from leaf and rhizome of Zingiber cassumunar Roxb. Bangladesh J. Pharmacol. 2008, 3, 69-73. [CrossRef]

20. Jitoe, A.; Masuda, T.; Mabry, T.J. Novel Antioxidants, Cassumunarin A, B, and C, from Zingiber cassumunar. Tetrahedron Lett. 1994, 35, 981-984. [CrossRef]

21. Jiang, H.; Xie, Z.; Koo, H.J.; McLaughlin, S.P.; Timmermann, B.N.; Gang, D.R. Metabolic profiling and phylogenetic analysis of medicinal Zingiber species: Tools for authentication of ginger (Zingiber officinale Rosc.). Phytochemistry 2006, 67, 1673-1685. [CrossRef]

22. Invasive Species Compendium. Available online: https://www.cabi.org/ISC/datasheet/57536 (accessed on 19 April 2019).

23. Nakatani, N.; Jitoe, A.; Masuda, T.; Yonemori, S. Flavonoid Constituents of Zingiber zerumbet Smith. Agric. Biol. Chem. 1991, 55, 445-460. [CrossRef]

24. Markham, K.R.; Chari, V.M. Carbon-13 NMR Spectroscopy of Flavonoids. In The Flavonoids; Harborne, J.B., Marby, T.J., Marby, H., Eds.; Chapman and Hall: New York, NY, USA, 1982; pp. 19-134. ISBN 978-1-4899-2915-0.

25. Masuda, T.; Jitoe, A.; Kato, S.; Nakatani, N. Acetylated flavonol glycosides from Zingiber zerumbet. Phytochemistry 1991, 30, 2391-2392. [CrossRef]

26. Xu, Y.; Smith, J.A.; Lannigan, D.A.; Hecht, S.M. Three acetylated flavonol glycosides from Forsteronia refracta that specifically inhibit p90 RSK. Bioorg. Med. Chem. 2006, 14, 3974-3977. [CrossRef] [PubMed] 
27. Dev, S. Studies in sesquiterpenes-XVI. Zerumbone, a monocyclic sesquiterpene ketone. Tetrahedron 1960, 8 , 171-180. [CrossRef]

28. Kitayama, T.; Okamoto, T.; Hill, R.K.; Kawai, Y.; Takahashi, S.; Yonemori, S.; Yamamoto, Y.; Ohe, K.; Uemura, S.; Sawada, S. Chemistry of Zerumbone. 1. Simplified isolation, conjugate addition reactions, and a unique ring contracting transannular reaction of its dibromide. J. Org. Chem. 1999, 64, 2667-2672. [CrossRef] [PubMed]

29. Chien, T.Y.; Chen, L.G.; Lee, C.J.; Lee, F.Y.; Wang, C.C. Anti-inflammatory constituents of Zingiber zerumbet. Food Chem. 2008, 110, 584-589. [CrossRef]

30. Ruslay, S.; Abas, F.; Shaari, K.; Zainal, Z.; Maulidiani; Sirat, H.; Israf, D.A.; Lajis, N.H. Characterization of the components present in the active fractions of health gingers (Curcuma xanthorrhiza and Zingiber zerumbet) by HPLC-DAD-ESIMS. Food Chem. 2007, 104, 1183-1191. [CrossRef]

31. Dai, J.R.; Cardellina, J.H.; McMahon, J.B.; Boyd, M.R. Zerumbone, an HIV-inhibitory and cytotoxic sesquiterpene of Zingiber aromaticum and Z. zerumbet. Nat. Prod. Lett. 1997, 10, 115-118. [CrossRef]

32. Kalantari, K.; Moniri, M.; Moghaddam, A.B.; Rahim, R.A.; Bin Ariff, A.; Izadiyan, Z.; Mohamad, R. A Review of the biomedical applications of zerumbone and the techniques for its extraction from ginger rhizomes. Molecules 2017, 22, 1645. [CrossRef]

33. Ho, Y.C.; Lee, S.S.; Yang, M.L.; Huang-Liu, R.; Lee, C.Y.; Li, Y.C.; Kuan, Y.H. Zerumbone reduced the inflammatory response of acute lung injury in endotoxin-treated mice via Akt-NFkB pathway. Chem. Biol. Interact. 2017, 271, 9-14. [CrossRef]

34. Mukherjee, D.; Singh, C.B.; Dey, S.; Mandal, S.; Ghosh, J.; Mallick, S.; Hussain, A.; Swapana, N.; Ross, S.A.; Pal, C. Induction of apoptosis by zerumbone isolated from Zingiber zerumbet (L.) Smith in protozoan parasite Leishmania donovani due to oxidative stress. Brazilian J. Infect. Dis. 2016, 20, 48-55. [CrossRef] [PubMed]

35. Sidahmed, H.M.A.; Hashim, N.M.; Abdulla, M.A.; Ali, H.M.; Mohan, S.; Abdelwahab, S.I.; Taha, M.M.E.; Fai, L.M.; Vadivelu, J. Antisecretory, gastroprotective, antioxidant and anti-Helicobcter pylori activity of zerumbone from Zingiber zerumbet (L.) smith. PLoS ONE 2015, 10, 1-21. [CrossRef] [PubMed]

36. Wang, C.; Zou, S.; Cui, Z.; Guo, P.; Meng, Q.; Shi, X.; Gao, Y.; Yang, G.; Han, Z. Zerumbone protects INS-1 rat pancreatic beta cells from high glucose-induced apoptosis through generation of reactive oxygen species. Biochem. Biophys. Res. Commun. 2015, 460, 205-209. [CrossRef] [PubMed]

37. Sehrawat, A.; Sakao, K.; Singh, S.V. Notch2 activation is protective against anticancer effects of zerumbone in human breast cancer cells. Breast Cancer Res. Treat. 2014, 146, 543-555. [CrossRef] [PubMed]

38. Shin, J.W.; Ohnishi, K.; Murakami, A.; Lee, J.S.; Kundu, J.K.; Na, H.K.; Ohigashi, H.; Surh, Y.J. Zerumbone induces heme oxygenase-1 expression in mouse skin and cultured murine epidermal cells through activation of Nrf2. Cancer Prev. Res. 2011, 4, 860-870. [CrossRef] [PubMed]

39. Saranya, J.; Dhanya, B.P.; Greeshma, G.; Radhakrishnan, K.V.; Priya, S. Effects of a new synthetic zerumbone pendant derivative (ZPD) on apoptosis induction and anti-migratory effects in human cervical cancer cells. Chem. Biol. Interact. 2017, 278, 32-39. [CrossRef]

40. Chen, B.; Lin, D.P.; Su, K.; Chen, Y.; Wu, C.; Teng, M.; Tsai, Y.; Sun, C.; Wang, S.; Chang, H. Dietary zerumbone prevents against ultraviolet B-induced cataractogenesis in the mouse. Mol. Vis. 2011, 723-730.

41. Chung, S.Y.; Jang, D.S.; Han, A.; Jang, J.O.; Kwon, Y.; Seo, E.; Lee, H.J. Modulation of P-glycoprotein-Mediated Resistance by Kaempferol Derivatives Isolated from Zingiber zerumbet. Phytother. Res. 2007, 569, 565-569. [CrossRef]

42. Subehan; Usia, T.; Kadota, S.; Tezuka, Y. Constituents of Zingiber aromaticum and their CYP3A4 and CYP2D6 inhibitory activity. Chem. Pharm. Bull. 2005, 53, 333-335. [CrossRef]

43. Usia, T.; Iwata, H.; Hiratsuka, A.; Watabe, T.; Kadota, S.; Tezuka, Y. Sesquiterpenes and flavonol glycosides from Zingiber aromaticum and their CYP3A4 and CYP2D6 inhibitory activities. J. Nat. Prod. 2004, 67, 1079-1083. [CrossRef]

44. Miyazaki, S.; Devkota, H.P.; Joshi, K.R.; Malla, K.J.; Watanabe, T.; Yahara, S. Chemical constituents from the aerial parts and rhizomes of Roscoea purpurea. Jpn. J. Pharmacogn. 2014, 68, 99-100. 
45. Akiyama, K.; Kikuzaki, H.; Aoki, T.; Okuda, A.; Lajis, N.H.; Nakatani, N. Terpenoids and a diarylheptanoid from Zingiber ottensii. J. Nat. Prod. 2006, 69, 1637-1640. [CrossRef] [PubMed]

46. Sivasothy, Y.; Hadi, A.H.A.; Mohamad, K.; Leong, K.H.; Ibrahim, H.; Sulaiman, S.F.; Ooi, K.L.; Awang, K. Spectaflavoside A, a new potent iron chelating dimeric flavonol glycoside from the rhizomes of Zingiber spectabile Griff. Bioorg. Med. Chem. Lett. 2012, 22, 3831-3836. [CrossRef] [PubMed] 